\title{
Neocortical $c$-fos mRNA transcription in repeated, brief, acute seizures: Is c-fos a coincidence detector?
}

\author{
ANDRÁS MIHÁLY ${ }^{1}$, SÁNDOR BORBÉLY ${ }^{4}$, ILDIKÓ VILÁGI ${ }^{4}$, LÁSZLÓ DÉTÁRI ${ }^{4}$, ROLAND WEICZNER ${ }^{1}$, \\ ZSOLT ZÁDOR $^{1}$, BEÁTA KRISZTIN-PÉVA ${ }^{1}$, ANDREA BAGOSI $^{1}$, ZSOLT KOPNICZKY $^{2}$ and ERNO ZÁDOR ${ }^{3}$ \\ Departments of ${ }^{1}$ Anatomy, ${ }^{2}$ Neurosurgery, ${ }^{3}$ Biochemistry, University of Szeged, Szeged; \\ ${ }^{4}$ Department of Physiology and Neurobiology, Eötvös Loránd University, Budapest, Hungary
}

Received July 28, 2004; Accepted November 8, 2004

\begin{abstract}
The effect of acute brief seizures on neocortical $c$-fos expression was investigated in rats injected with $5 \mathrm{mg} / \mathrm{kg}$ 4-aminopyridine. Electroencephalography in freely moving animals with implanted neocortical electrodes detected an average of 2.67 tonic-clonic convulsions within $1 \mathrm{~h}$ following the 4-AP treatment. Tissue samples of the somatosensory neocortex were collected at $30 \mathrm{~min}, 1 \mathrm{~h}, 3 \mathrm{~h}, 5 \mathrm{~h}$ and $8 \mathrm{~h}$ following the treatment for PCR and immunohistochemistry. The $c$-fos mRNA displayed the first significant rise at $1 \mathrm{~h}$, and remained significantly higher through $3 \mathrm{~h}$. The number of c-fos protein immunoreactive cells was significantly elevated already at $30 \mathrm{~min}$, peaked at $1 \mathrm{~h}$, and declined by $5 \mathrm{~h}$. We conclude that in repetitive, brief seizures, the first convulsion does not increase $c$-fos RNA transcription, whilst the second causes a long-lasting gene expression and a large increase of c-fos protein synthesis. The phenomenon may have implications in the pathogenesis of human and animal epilepsies.
\end{abstract}

\section{Introduction}

In human epileptic case histories, the first symptom towards a long-lasting pathological change is very often an acute, unprecedented convulsion. Patients experiencing 1-2 unprecedented, idiopathic seizures have an increased risk for the development of epilepsy (1). Therefore, the detailed analysis of the molecular events of an acute seizure might provide useful information concerning the pathogenesis of epilepsy. The expression of the Fos family member protooncogenes is induced in every animal seizures studied so far, indicating that the activation of the $c$-fos promoter may be an

Correspondence to: Dr András Mihály, Department of Anatomy, Faculty of Medicine, University of Szeged, P.O. Box 427, H-6701 Szeged, Hungary

E-mail:mihaly@anatomy.szote.u-szeged.hu

Key words: epilepsy, cerebral cortex, 4-aminopyridine, gene expression, $c$-fos, rat early common pathway in the convulsive state (2-5). Therefore, combined with the electrophysiological analysis of the acute seizure on freely moving animals, we applied the reverse transcription polymerase chain reaction (RT-PCR) to detect time-related changes of the transcription of the $c$-fos gene, and used immunohistochemistry to track the translation of c-fos protein. We compared the transcription dynamics of the $c$-fos gene to the appearance of c-fos immunoreactive (c-fosIR) cell nuclei, and to the electrophysiological and behavioural symptoms. In the present experiments, we utilized 4-aminopyridine (4-AP), a specific $\mathrm{K}^{+}$-channel blocker, which precipitates well-described acute behavioural convulsions in experimental animals (5-7).

\section{Materials and methods}

Male Wistar rats (200-250 g bwt) bred in the Central Animal House of Szeged University were used. The animals were kept in standard conditions with free access to water and food. The animal experiments were in accordance with the European Community Council Directive of November 24, 1986 (86/609/EEC) and the Hungarian Animal Act (1998). Seizures were induced with a single intraperitoneal (i.p.) injection of 4-AP (Sigma; $5 \mathrm{mg} / \mathrm{kg} 4-\mathrm{AP}$, dissolved in physiological saline, $1.0 \mathrm{mg} / \mathrm{ml}$ concentration). Control animals received the same volume of physiological saline, i.p. (Table I).

The animals were deeply anesthetised with Nembutal $(50 \mathrm{mg} / \mathrm{kg}$, i.p.) and their heads fixed in a stereotaxic frame. Stainless steel screw-electrodes were implanted over the somatosensory cortex (trunk and hindlimb regions) on both sides according to the stereotaxic coordinates (8). An additional screw electrode over the cerebellum served as a reference. Electrode leads were attached to a miniature socket fixed to the skull with dental acrylic cement. Following a 10 dayrecovery period, the electrodes were connected to the recording instrument through slip-ring assemblies. The behaviour of the animals was monitored continuously with video cameras.

Spontaneous EEG signals were recorded before seizure induction. The EEG activity was recorded continuously for $8 \mathrm{~h}$ following the 4-AP treatment. Signals were amplified 1000fold with a commercial multichannel amplifier, filtered between $0.3-50 \mathrm{~Hz}$, digitised at a sampling rate of $100 \mathrm{~Hz}$ 
Table I. Experimental groups and the number of animals.

\begin{tabular}{|c|c|c|c|}
\hline Experiments & $\begin{array}{l}\text { Number of rats } \\
\text { in the control } \\
\text { (saline-treated) groups }\end{array}$ & $\begin{array}{l}\text { Number of rats } \\
\text { treated with } \\
\text { 4-AP }\end{array}$ & $\begin{array}{l}\text { Recording/sampling times } \\
\text { after 4-AP injection and in } \\
\text { controls after saline injection }\end{array}$ \\
\hline Electrophysiology (EEG) & (self control) & 5 & $30 \mathrm{~min}, 1 \mathrm{~h}, 3 \mathrm{~h}, 5 \mathrm{~h}, 8 \mathrm{~h}$ \\
\hline Immunohistochemistry & 15 & 15 & $30 \mathrm{~min}, 1 \mathrm{~h}, 3 \mathrm{~h}, 5 \mathrm{~h}, 8 \mathrm{~h}$ \\
\hline Gene expression analysis (RT-PCR) & 15 & 15 & $30 \mathrm{~min}, 1 \mathrm{~h}, 3 \mathrm{~h}, 5 \mathrm{~h}, 8 \mathrm{~h}$ \\
\hline
\end{tabular}

Table II. Features of the EEG seizure activity following 4-AP administration. ${ }^{a}$

\begin{tabular}{lcccccccc}
\hline & $\begin{array}{c}\text { Duration } \\
\text { of first } \\
\text { seizure } \\
(\mathrm{sec})\end{array}$ & $\begin{array}{c}\text { Duration } \\
\text { of first } \\
\text { tonic phase } \\
(\mathrm{sec})\end{array}$ & $\begin{array}{c}\text { Duration } \\
\text { of first } \\
\text { clonic phase } \\
(\mathrm{sec})\end{array}$ & $\begin{array}{c}\text { Duration } \\
\text { of second } \\
\text { seizure } \\
(\mathrm{sec})\end{array}$ & $\begin{array}{c}\text { Duration } \\
\text { of second } \\
\text { tonic phase } \\
(\mathrm{sec})\end{array}$ & $\begin{array}{c}\text { Duration } \\
\text { of second } \\
\text { clonic phase } \\
(\mathrm{sec})\end{array}$ & $\begin{array}{c}\text { Frequency } \\
\text { in tonic } \\
\text { phases } \\
(\mathrm{Hz})\end{array}$ & $\begin{array}{c}\text { Frequency } \\
\text { in clonic } \\
\text { phases } \\
(\mathrm{Hz})\end{array}$ \\
\hline Mean $(\mathrm{n}=5)$ & 53.53 & 7.38 & 46.15 & 73.44 & 8.96 & 64.48 & 7.77 & 5.23 \\
SD & 4.21 & 4.10 & 5.12 & 13.94 & 5.26 & 15.30 & 1.21 & 0.98 \\
\hline
\end{tabular}

${ }^{a}$ No statistical analysis was performed on the EEG data.

and stored on computer for off-line analyses. Epileptiform discharges were analysed with custom written software.

In the RT-PCR experiments, we used 30 rats: three controls and three 4-AP-treated animals at each sampling time (Table I). The 4-AP treated rats always displayed behavioural seizures. The rats were decapitated under diethyl-ether anaesthesia, the brains were dissected, samples of the somatosensory neocortex were frozen in liquid nitrogen, homogenized, and total RNA was extracted by the AGPC method (9). The reverse transcription (RT) was made from $2 \mu \mathrm{g}$ RNA (10). The RT product $(1 \mu \mathrm{l}$ of the $20 \mu \mathrm{l})$ was submitted to multiplex polymerase chain reaction (PCR) in $50 \mu$ volume of Taq reaction buffer containing $0.05 \mu \mathrm{M}$ glyceraldehyde-3phosphate dehydrogenase (GAPDH) primers, $0.5 \mu \mathrm{M} c$-fos primers, $200 \mu \mathrm{M}$ dNTP, $1.5 \mathrm{mM} \mathrm{MgCl}{ }_{2}$ and one unit of DNA polymerase. The sequence of GAPDH primers (10) and the sequence of $c$-fos primers (11) have already been described. Amplification was carried out in 25 cycles after carefully establishing the linearity for both the GAPDH and $c$-fos fragments between 20 and 30 cycles. Identity of the $c$-fos PCR fragment (256 bp) and the GAPDH fragment (377 bp) was confirmed by cloning into and sequencing a pGEM-T easy vector. The RT-PCR products were separated on $6 \%$ acrylamide gel and stained with ethidium bromide. Densitometric scanning using ImageQuant (Typhoon ${ }^{\mathrm{TM}} 9400$ Variable Mode Imager, Molecular Dynamics) was performed for the quantification of the bands. The Student's t-test and Newman-Keuls test were used for statistical analysis. The level of $c$-fos transcripts in the samples was normalized to the level of GAPDH mRNA detected from the same amplification.

For immunohistochemistry, brains were fixed by transcardiac perfusion (4\% paraformaldehyde in $0.1 \mathrm{M}$ phosphate buffer; pH 7.4). Frozen, coronal plane sections were cut at $20 \mu \mathrm{m}$ thickness with cryostat. Polyclonal $c$-fos antibody (raised in rabbit; Santa Cruz Biotechnology, CA, USA) and the peroxidase-antiperoxidase (PAP) method was used for immunohistochemistry. The sections were incubated in $20 \%$ normal pig serum, next in primary $c$-fos antibody ( $1: 1000$ in $20 \%$ normal pig serum), and then in donkey antirabbit IgG (1:40; Jackson Immuno-Research, PA, USA). The secondary antibody was detected by PAP complex diluted to 1:1000 (Jackson). The peroxidase reaction was localised with nickel chloride-containing diaminobenzidine tetrahydrochloride (Sigma), yielding a black reaction product.

From every animal, five coronal immunohistochemical sections of identical stereotaxic coordinates were selected. Within the areas of interest (AOIs), the immunoreactive cell nuclei were counted using a Nikon Eclipse 600 microscope equipped with a Spot RT Slider digital camera (1600x1200 dpi in 8 bits), using the Image Pro Plus 4.5 morphometry software (Media Cybernetics, Silver Spring, MD, USA). The counting was performed blinded to the animal treatment. Cell counts in the S1Tr region of the neocortex (8) were done by using a 10x objective. The AOI size $\left(0.25 \mathrm{~mm}^{2}\right)$ was the rectangular image-capturing field of the camera which included each neocortical layer (I-VI), so that the layers could be evaluated separately. Frozen sections stained with cresyl violet were used as reference for the thickness of the neocortical layers. The data were analysed statistically comparing sets of findings obtained with the same magnification. Cell counts were normalised to $1 \mathrm{~mm}^{2}$. Differences in the number of c-fosIR cells in the control and convulsing animals were analysed with one-way analysis of variance (ANOVA), followed by the Bonferroni post hoc test. A significance criterion of 0.05 was used. The statistical analysis was performed with SPSS 9.0 software. 

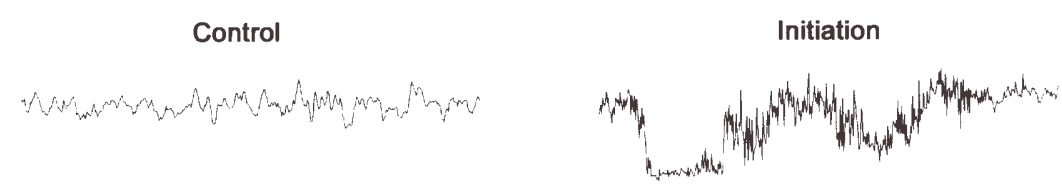

Tonic phase

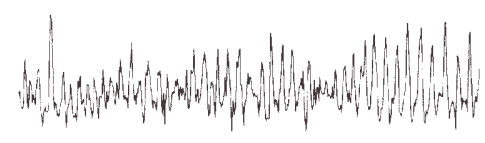

Clonic phase II

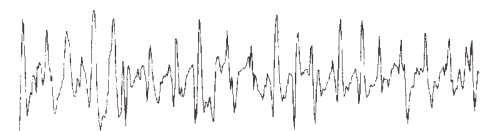

Clonic phase I

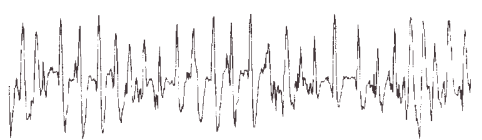

Termination

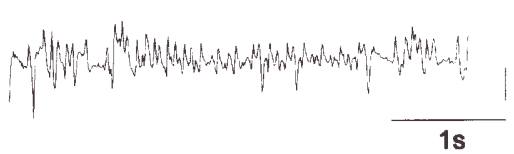

Figure 1. Following 4-AP treatment, neocortical seizure activity appeared in each animal. The representative parts of the records are from control animals, before the injection of 4-AP (Control), and during the seizure (Initiation, Tonic phase, Clonic phase I, Clonic phase II, Termination). Time and voltage scales are shown.

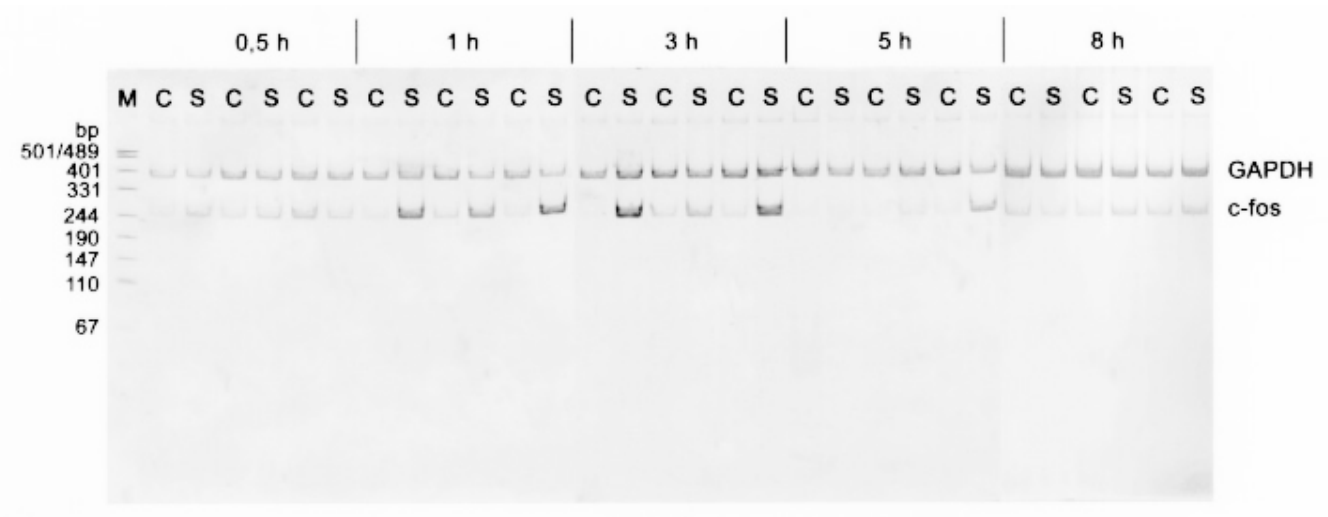

Figure 2. Polyacrylamide gel analysis of fragments of multiplex RT-PCR reactions. The upper bands show GAPDH, the lower bands $c$-fos. The first lane (M) displays length markers. S, neocortex of 4-AP-treated animals; C, neocortex of rats injected with physiological saline.

\section{Results}

The i.p. administration of 4-AP induced generalised tonicclonic seizures. During the 8-hour-recording period, two seizures were detected in each animal except one, in which three events occurred. The convulsions appeared during the first hour of the observation. The behavioural sequel of 4-AP seizures was described in detail previously (7). The first seizure activity appeared on the EEG with an average latency of $20.70 \pm 6.48 \mathrm{~min}$. This event was followed by a second seizure, and the mean delay between the two seizure events was $16.22 \pm 4.86 \mathrm{~min}$. The mean duration of the first discharges was $53.53 \pm 4.21 \mathrm{sec}$, while the second was significantly longer, lasting for $73.44 \pm 13.94 \mathrm{sec}$ (Table II). Repetitive spikes characterized each seizure event in the so-called tonic phase and repetitive spikes at a smaller frequency, as well as spike-and-wave complexes in the so-called clonic phase
(Fig. 1, Table II). The EEG seizure and the behavioural symptoms did not last longer than $1 \mathrm{~h}$.

The mRNA of $c$-fos was detectable in the neocortex of control and 4-AP treated rats, as was the internal control GAPDH mRNA (Fig. 2). In control and 4-AP-treated rats, GAPDH messages were not different. At 30 min following the treatment, no increase of the intensity of the $c$-fos mRNA signal was detected. At $1 \mathrm{~h}$ following the 4-AP treatment, the level of $c$-fos mRNA increased significantly $(\mathrm{P}=0.0134)$. This increase of $c$-fos mRNA in 4-AP treated animals was also maximal and highly significant, compared to levels detected at other time points (Fig. 3). At $3 \mathrm{~h}$, the increase (compared to controls) was at the border of significance $(\mathrm{P}=0.0617)$. After that, $c$-fos mRNA decreased gradually below the control level by $8 \mathrm{~h}$ (Fig. 3).

The c-fosIR cell nuclei were present in every layer of the neocortex following 4-AP administration (Fig. 4). The increase 


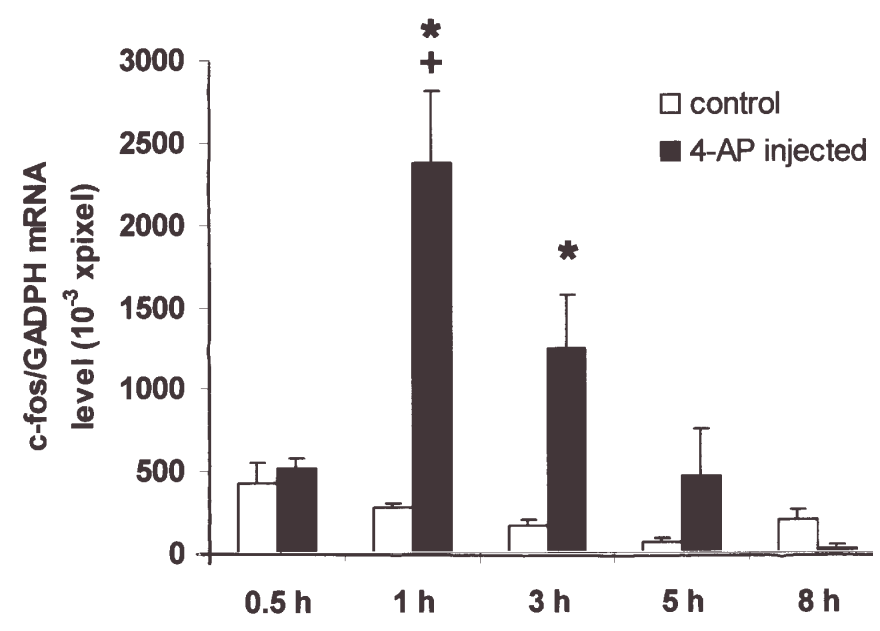

Figure 3. Diagram of c-fos mRNA levels after normalization to the coamplified GAPDH mRNA. Black columns show the mean values of 4-AP treated animals, white columns show the mean values of physiological saline treated rats, vertical bars represent \pm SE. The differences compared to controls are significant at 1 and $3 \mathrm{~h}$ (*). The differences between convulsing animals are very significant at $1 \mathrm{~h}$ compared to $0.5,5$ and $8 \mathrm{~h}(+)$. Labels: (+) very significant difference (Newman-Keuls test, $\mathrm{P}=0.0134$ ); (*) significant difference (paired t-test, $\mathrm{P}=0.0617$ ).

of the number of c-fosIR cell nuclei was significant already at $30 \mathrm{~min}$ in layers II, III, IV, V and VI. The highest values were detected at $1 \mathrm{~h}$ in each layer. The increase was still significant at $3 \mathrm{~h}$ following 4 -AP injection. Cell counts decreased to control levels at 5 and $8 \mathrm{~h}$ following 4-AP administration (Fig. 5). The highest elevation in the number of c-fosIR cells at 30 min was seen in layer IV: other layers contained less c-fosIR cells. At $1 \mathrm{~h}$, every layer (except layer I) stained strongly; only layer V stood out with a lower amount of c-fosIR cells. At $3 \mathrm{~h}$, the number of c-fosIR cells decreased slightly in layers II, III, IV, V and VI. At $5 \mathrm{~h}$, the cell numbers decreased to control levels, and remained so at $8 \mathrm{~h}$ (Fig. 5). The values in convulsing animals displayed highly significant differences $(\mathrm{P} \leq 0.01)$ compared to the controls (Fig. 5). In controls, scattered c-fosIR cells were seen in layer IV (Fig. 5).

\section{Discussion}

Previous studies from our laboratory indicated that the 4-AP model is reliable for the investigation of seizure genesis, and that careful counting of c-fosIR cell nuclei serves as an indicator of seizure spread in forebrain structures, in vivo $(5,12)$. In the present experiments, the RT-PCR studies demonstrated the time-related induction, increase and decrease of the $c$-fos mRNA in the cerebral cortex following 4-AP injection. This is the first such report in the literature of 4-AP seizures. Another important observation in the present experiments is that the activation of the $c$-fos gene lasted significantly longer than the electrophysiological and behavioural seizure.

In our experiments, one dose of intraperitoneally applied 4-AP induced at least two seizure events in the animals: this is what we call brief, repetitive convulsions. In a similar series of experiments with $5 \mathrm{mg} / \mathrm{kg} 4-\mathrm{AP}$, only $70 \%$ of the rats was affected and usually only one tonic-clonic seizure was detected (6). Compared to our results, the latency of the seizures was similar, only the duration of the events was somewhat shorter (6).

Timing of the events was relatively uniform; SD was only $6.48 \mathrm{~min}$ in case of the first seizure and $4.86 \mathrm{~min}$ for the time between the seizures. These values are similar to that we detected with the measuring of the latencies of the symptoms: in those experiments, the latency of the first tonic-clonic seizure was $25.8 \pm 1.9 \mathrm{~min}(7)$. The standard latency of the first generalised convulsion proves the reliability of the 4-AP model: indicates that 4-AP penetrates the brain barriers evenly, and that the elimination of the drug follows a standard kinetics (13). Our findings concerning the appearance of $c$-fos in the convulsing brain are in accordance with previous reports $(2,4)$.

The duration of the second EEG seizure was longer than that of the first significantly, indicating the sensitization of large neuronal populations following the first convulsion. In the neocortex, pyramidal cell interactions are very effective, probably because of the high cellular density and high degree of axonal collateralization (14). The pyramidal-to-pyramidal cell excitatory synapses mainly use NMDA receptors; therefore they exhibit self-facilitation (14). The result is the reverberant excitatory activity within a pool of interconnected pyramidal cells (14). Our recent experiments with in vivo microdialysis proved that 4-AP convulsions were accompanied by a large and long-lasting increase of glutamate release (15). Moreover, seizure events and $c$-fos expression were dependent on NMDA-type glutamate receptors (5). Therefore, we think that the sharp increase of $c$-fos mRNA in the neocortex reflects the activation of ionotropic (mainly NMDA-type) glutamate receptors.

However, the effects of the two repetitive seizure episodes were different. The first seizure (appearing at $20 \mathrm{~min}$ ) did not generate an increase in $c$-fos mRNA level, as measured at the 30 min RT-PCR sampling time. The second seizure (appearing 30-40 min after the injection) boosted the transcription of $c$-fos, causing a highly significant elevation at $1 \mathrm{~h}$, as shown by the RT-PCR measurements.

On the other hand, the number of c-fosIR cell nuclei was significantly elevated already at $30 \mathrm{~min}$, indicating that a large amount of Fos-protein entered the neuronal cell nuclei at the time when $c$-fos mRNA levels were not yet elevated. This discrepancy raises the possibility of the seizure-activated translocation of the Fos-protein from the cytoplasm to the nucleus. Literature data indicate that the intranuclear translocation of the Fos-protein depends on extracellular signals (16). Our observations support these data and suggest that neuronal depolarization and the rise of intracellular $\mathrm{Ca}^{++}$ level stimulate the translocation of the c-fos protein (16) from the cytoplasm to the cell nucleus. The analysis of the different neocortical layers revealed that lamina IV displayed the most c-fosIR cells at $30 \mathrm{~min}$, indicating that the activation of the neocortex probably happened through the thalamocortical projections (17). This layer retained a relatively high number of stained cells after $3 \mathrm{~h}$, suggesting that the thalamocorticalcorticothalamic circuits are important in the maintenance of synchronized neocortical activity (18). Our previous rCBF measurements proved the large increase of $\mathrm{rCBF}$ in the dorsal diencephalon and the neocortex in 4-AP seizures in mice (19). Following this line of evidence, we conclude that in acute 


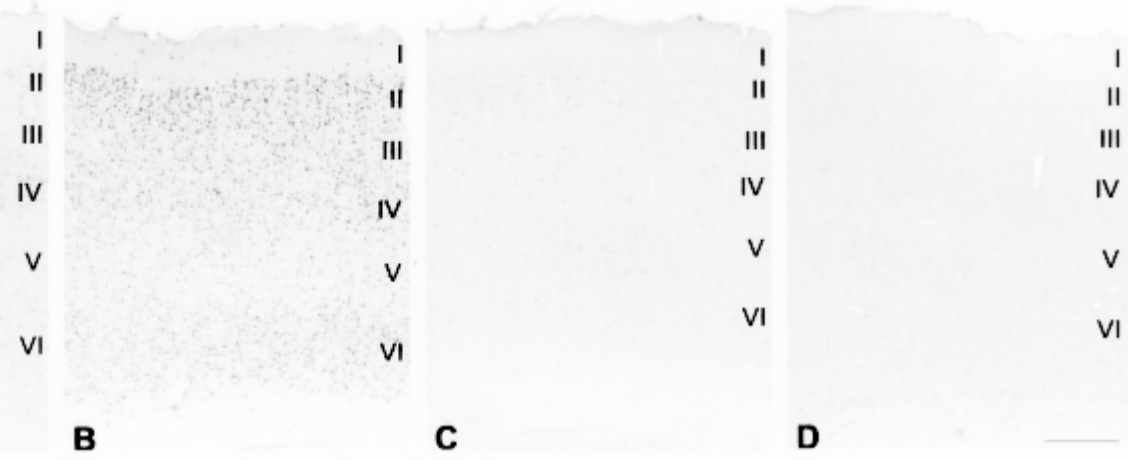

Figure 4. Immunohistochemistry of c-fos protein in the S1Tr neocortex in 4-AP-injected animals (A, 30 min; B, 1 h; C, 3 h; D, 5 h). Controls are not shown because they display a staining pattern similar to D. Roman numerals indicate neocortical layers; bar, $500 \mu \mathrm{m}$.
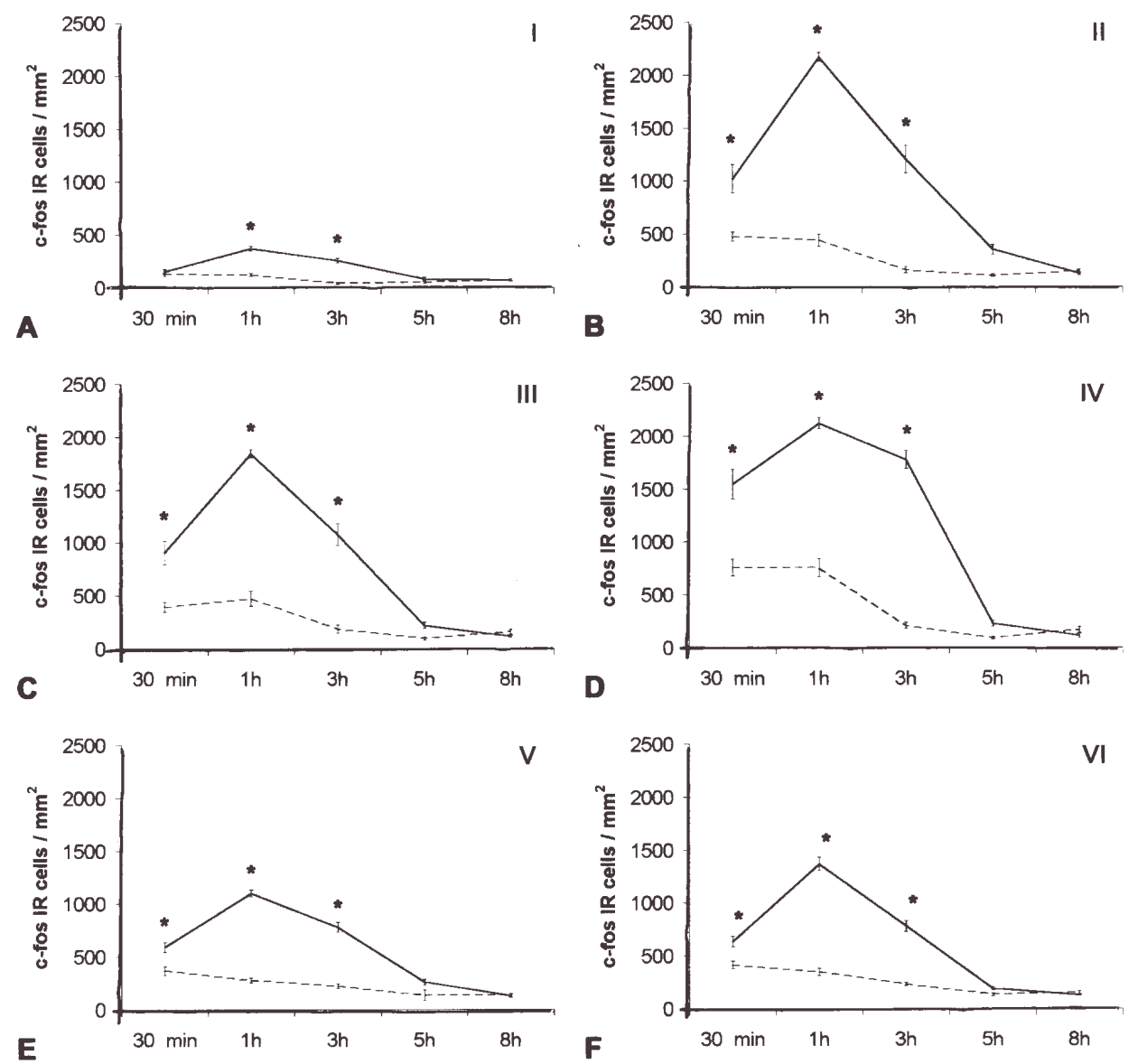

Figure 5. Results of the counting of c-fosIR cell nuclei in the neocortex: cell counts in 4-AP seizures at $30 \mathrm{~min}, 1 \mathrm{~h}, 3 \mathrm{~h}, 5 \mathrm{~h}$ and $8 \mathrm{~h}$. Solid lines represent cell counts in 4-AP-treated rats, broken lines represent controls and vertical bars represent \pm SE. We noted that the control and 4-AP treated groups differ significantly in every cases at 1 and $3 \mathrm{~h}(\mathrm{~A}-\mathrm{F})$, and also at $30 \mathrm{~min}$ in layers II, III, IV, V, VI (B-F). Asterisks denote significant difference (P<0.01). A, layer I; B, layer II; C, layer III; D, layer IV; E, layer V; F, layer VI. Slight, non-specific elevation in control animals was due to the handling during the experiment.

neocortical seizure the first cellular event [mediated by the synchronised activity of thalamocortical afferents (18) during the first EEG convulsion] is the stimulated translocation of cytoplasmic c-fos protein to the nucleus, where it binds to the AP-1 sequence, and can participate in transactivation processes (3). The second EEG seizure event caused the accumulation of the molecular activators of the $c$-fos promoter, and the large induction of $c$-fos transcription, as shown by the $1 \mathrm{~h}$ peak of $c$-fos mRNA. This process could be the result of the strong activation of $\mathrm{Ca}^{++}$-permeable glutamate receptors in consequence of seizure-induced intracortical pyramidalpyramidal cell interactions (14). At $3 \mathrm{~h}$, both $c$-fos mRNA and protein decreased, indicating the decrease of the transcription and the slow enzymatic breakdown of the synthesized c-fos protein. Literature data prove that the breakdown occurs via the ubiquitin/proteasome pathway, indicating that not only 
the transcription and translation but also the degradation are strictly controlled processes (20).

Summarizing our results, we conclude that upon the effect of the first brief convulsion, Fos-proteins move into the cell nucleus, where they bind to the AP-1. Therefore, the next convulsion will find functioning c-fos-activated AP-1, and the effects in terms of transcriptional regulation will be greater. Based on these results, we think that $c$-fos (and probably other IEGs) may act as metaconvulsive agents (21), facilitating the forthcoming seizure. We propose that similarly to memory (21), IEGs also act as coincidence detectors, potentiating the long-time cellular effects of successive, brief seizures. This process of potentiation and the coincidence detector effect of the IEGs may have significance in the pathogenesis of those idiopathic human epilepsies, which develop due to unprecedented acute convulsions.

\section{Acknowledgements}

The experiments were supported by grants from the Hungarian National Research Fund and Ministry of Education (OTKA T 32566 and OMFB-1921/2002) and the British Council (GB-8/2003). The manuscript was completed during the author's (AM) stay in the Department of Anatomy, University of Bristol, UK.

\section{References}

1. Shinnar S and Hauser WA: Do occasional brief seizures cause detectable clinical consequences? In: Do Seizures Damage The Brain? Sutula T and Pitkänen A (eds). Prog Brain Res 135: 221-235, 2002.

2. Gass P, Herdegen T, Bravos R and Kiessling M: Induction of immediate early gene encoded proteins in the rat hippocampus after bicuculline-induced seizures: differential expression of KROX-24, fos and jun proteins. Neuroscience 48: 315-324, 1992.

3. Herdegen $\mathrm{T}$ and Leah JD: Inducible and constitutive transcription factors in the mammalian nervous system: control of gene expression by Jun, Fos and Krox, and CREB/ATF proteins. Brain Res Rev 28: 370-490, 1998.

4. Morgan JI and Curran T: Proto-oncogene transcription factors and epilepsy. Trends Pharmacol Sci 12: 343-349, 1991.

5. Szakács R, Weiczner R, Mihály A, Krisztin-Péva B, Zádor Z and Zádor E: Non-competitive NMDA receptor antagonists moderate seizure-induced $c$-fos expression in the rat cerebral cortex. Brain Res Bull 59: 485-493, 2003.
6. Fragoso-Veloz J, Massieu L, Alvarado R and Tapia R: Seizures and wet-dog shakes induced by 4-aminopyridine, and their potentiation by nifedipine. Eur J Pharmac 178: 275-284, 1990.

7. Mihály A, Bencsik K and Solymosi T: Naltrexone potentiates 4-aminopyridine seizures in the rat. J Neural Transmiss (GenSect) 79: 59-67, 1990.

8. Paxinos $\mathrm{G}$ and Watson C: The Rat Brain in Stereotaxic Coordinates. Academic Press, San Diego, CA, 1998.

9. Chomczynski P and Sacchi N: Single-step method of RNA isolation by acid guanidium thiocyanate-phenol-chloroform extraction. Anal Biochem 162: 156-159, 1987.

10. Zádor E, Mendler L, Ver Heyen M, Dux L and Wuytack F: Changes in mRNA levels of the sarcoplasmic/endoplasmic reticulum $\mathrm{Ca}^{2+}$ ATPase isoforms in the rat soleus muscle regenerating from notexin-induced necrosis. Biochem J 320: 107-113, 1996.

11. Arrieta I, Camacho-Arroyo I, Mendoza-Rodríez CA, Cerbon MA: $c$-fos gene expression pattern in the hypothalamus and the preoptic area of defeminized rats. Brain Res 867: 100-106, 2000.

12. Mihály A, Szakács R, Bohata Cs, Dobó E and Krisztin-Péva B: Time-dependent distribution and neuronal localization of c-fos protein in the rat hippocampus following 4-aminopyridine seizures. Epilepsy Res 44: 97-108, 2001.

13. Lemeignan M, Millart H, Lamiable D, Molgo J and Lechat P: Evaluation of 4-aminopyridine and 3,4-diaminopyridine penetrability into cerebrospinal fluid in anesthetized rats. Brain Res 304: 166-169, 1984.

14. Thomson AM and Deutchard J: Temporal and spatial properties of local circuits in neocortex. Trends Neurosci 17: 119-126, 1994.

15. Kovács A, Mihály A, Komáromi A, Gyengesi E, Szente M, Weiczner R, Krisztin-Péva B, Szabó G and Telegdy G: Seizure, neurotransmitter release, and gene expression are closely related in the striatum of 4-aminopyridine-treated rats. Epilepsy Res 55: 117-129, 2003.

16. Roux P, Blanchard JM, Fernandez A, Lamb N, Jeanteur P and Piechaczyk M: Nuclear localization of c-fos, but not v-fos proteins, is controlled by extracellular signals. Cell 63: 341-351, 1990.

17. Freund TF, Martin KA, Soltesz I, Somogyi P and Whitteridge D: Arborisation pattern and postsynaptic targets of physiologically identified thalamocortical afferents in striate cortex of the macaque monkey. J Comp Neurol 289: 315-336, 1989.

18. Steriade $M$ and Contreras D: Relations between cortical and thalamic cellular events during transition from sleep patterns to paroxysmal activity. J Neurosci 15: 623-642, 1995.

19. Mihály A, Shihab-Eldeen A, Owunwanne A, Gopinath S, Ayesha A and Mathew M: Acute 4-aminopyridine seizures increase the regional cerebral blood flow in the thalamus and neocortex, but not in the entire allocortex of the mouse brain. Acta Physiol Hung 87: 43-52, 2000.

20. Acquaviva C, Bossis G, Ferrara P, Brockly F, Jariel-Encontre I and Piechaczyk M: Multiple degradation pathways for Fos family proteins. Ann NY Acad Sci 973: 426-434, 2002.

21. Guzowski JF: Insights into immediate-early gene function in hippocampal memory consolidation using antisense oligonucleotide and fluorescent imaging approaches. Hippocampus 12: 86-104, 2002. 